\title{
Disclosure and minority expropriation: A study of French listed
}

\section{firms}

\author{
Chiraz Ben Ali (Université Paris Dauphine)
}

\begin{abstract}
:
In this paper we examine the influence of minority expropriation on disclosure level in France where shareholders are poorly protected and the main agency problem is the one between controlling and minority shareholders (type II conflict) while prior studies have been undertaken in the United States, in a context of ownership dispersion and high investor protection where the main agency conflict opposes managers to shareholders (type I conflict).

Using a sample of 81 French firms on the 2001-2004 period, we find a negative relation between disclosure level and both ownership and control concentration and double voting rights shares. These results confirm that type II conflict exacerbates the disclosure problem. Controlling shareholders benefit from superior information which helps them to profit from private benefits at the expense of minority shareholders particularly when they hold voting rights in excess of their cash flow rights; therefore they are likely to reduce disclosure.

Our results show also a positive relation between disclosure level and family control which is similar to Ali, Chen et Radhakrishnan (2007) findings on American firms.
\end{abstract}

Key words: corporate governance, minority expropriation, ownership structure

\section{Résumé}

Ce papier examine l'influence de l'expropriation des actionnaires minoritaires sur le niveau de divulgation en France où les investisseurs sont faiblement protégés et le conflit d'agence principal est celui opposant les actionnaires de contrôle aux actionnaires minoritaires (conflit d'agence de type II). Cependant, la plupart des études précédentes ont été menées aux Etats-Unis où l'environnement légal offre aux investisseurs une protection élevée et la propriété est dispersée d'où l'intérêt au conflit d'agence traditionnel opposant les actionnaires aux managers (conflit d'agence de type I).

A partir d'un échantillon de 81 entreprises françaises sur la période 2001-2004, nous trouvons une relation négative entre le niveau de divulgation et la concentration du capital et du contrôle et l'existence de droit de vote double. Ces résultats confirment que le conflit d'agence de type II accentue le problème de divulgation. Les actionnaires de contrôle bénéficient d'un avantage informationnel comparés aux actionnaires minoritaires leur permettant de profiter des bénéfices privés du contrôle au détriment des actionnaires minoritaires, ils réduisent le niveau de divulgation afin d'éviter la contestation des actionnaires minoritaires. Le risque d'expropriation est d'autant plus élevé lorsque les actionnaires de contrôle disposent de droits de vote en excès par rapport à leurs droits de capital ce qui les pousse à réduire le niveau de divulgation. Concernant, l'influence du contrôle familial, nos résultats sont similaires à ceux trouvés par Ali, Chen et Radhakrishnan (2007) sur des données américaines à savoir : il existe une relation positive entre le niveau de divulgation et le contrôle familial.

Mots clés : gouvernement d'entreprise, expropriation des minoritaires, structure de propriété.

\section{Corresponding author}

Chiraz Ben Ali

CREFIGE

Université Paris Dauphine

Place Maréchal de Lattre de Tassigny

75775 cedex 16 Paris- France 


\section{Introduction}

Corporate governance has been criticized following the financial crisis of 2001 due to financial scandals (Enron, WorldCom...) that shed light on the importance of the corporate governance issue. Manipulation of accounting numbers and disclosure of false information in Enron showed that minority shareholders rights are not always protected. The main contests that Enron' shareholders have signaled are non disclosure of relevant information, delaying reporting losses, and disclosure of false information. These bankruptcies lead legal authorities to develop new regulations in order to improve shareholders information, for example the Sarbanes Oxley Act (SOX) in the USA, the directive 2004/109/CE of the European Parliament and Council called "transparency directive", and the LSF act in France. Those scandals proved that shareholders are not homogenous. In opposition to individual shareholders who hold limited resources to obtain information about the firm, controlling shareholders often participate in the firms' management, and therefore they can obtain private information which gives them opportunities to expropriate minority shareholders; this situation leads to an agency conflict opposing controlling shareholders to non-controlling shareholders (type II conflict). However, previous studies have focused on the agency conflict between managers and shareholders (type I conflict) (Fama et Jensen, 1983). Nevertheless recent studies have shown the prevalence of ownership concentration and the validity of the agency conflict between controlling shareholders and minority shareholders (Shleifer et Vishny, 1997 ; La Porta et al., 1998 ; La Porta, Lopez-de-Silances et Shleifer, 1999 ; La Porta et al., 2000 ; Faccio et Lang, 2002).

Controlling shareholders have incentives to exploit private benefit at the expense of minority shareholders interest. Because of their proximity to operating activity, they can obtain private information to evaluate their investment return and are therefore reluctant to disclose information to public in order to avoid minority contest and continue to expropriate other shareholders. Controlling shareholders usually have voting rights in excess of their cash flow rights (La Porta, Lopez-de-Silances et Shleifer, 1999); consequently they don't support all the consequences of their decisions. The separation between ownership and control exacerbate the minority expropriation risk. Family shareholders participate actively in the management; entrenched managers are more likely to execute the family's plan at the expense of other shareholders. 
This paper examines the impact of minority expropriation on the disclosure level of French firms. In particular, we study the effect of factors that influence minority expropriation which deals with ownership and control concentration (Gelb, 2000 ; Fan et Wong, 2002 ; Labelle et Schatt, 2005), the separation between cash flow and voting rights (Grossman et Hart, 1988 ; Harris et Raviv, 1988), and family ownership (Chau et Gray, 2002).

We analyze a sample of 81 French firms over the 2001-2004 period. We measure disclosure quality using an indirect measure: analyst earning forecast dispersion and find a negative relation between disclosure level and both ownership and control concentration. First, we conclude that under high ownership concentration, controlling shareholders are less reliant on minority shareholders and are likely to expropriate benefits from them; therefore they have less incentive to disclose information. Second, when the controlling shareholder has high voting percentage, the entrenchment effect is exacerbated because he doesn't need the complicity of other shareholders to increase the chance of approval of one decision submitted to the general meeting.

The results show also a negative relation between the existence of double voting rights shares and disclosure level. When controlling shareholders hold cash flow rights in excess of their control rights, they do not support all the consequences of their decisions which increase their incentives to expropriate minority shareholders. Therefore, they also have little incentive to disclose information to protect themselves.

We find that family controlled firms present better disclosure level than non family firms. This result is similar with Ali et al. (2007) findings that family firms report better quality earnings and are more likely to warn for a given magnitude of bad news. Because of the non separation between management and ownership, family firms face more severe type II conflict and less severe type I conflict. Our results are consistent with the view that the decrease in type I conflict exceed the increase in type II conflict which posits that family firms are likely to present better disclosure quality.

We extend prior studies of voluntary disclosure in four ways. First, our paper adds to the growing literature on the conflict of controlling shareholders with minority shareholders. Most of the studies that examine disclosure have been conducted in USA or UK where individual shareholders are protected which result in ownership dispersion and focus on the agency conflict between managers and shareholders. Our study extends previous research by examining disclosure transparency in an environment of poor investor protection like France 
(La Porta et al., 2000) leading to ownership concentration and the raise of an agency conflict between controlling and minority shareholders because of lower law enforcement to protect minority rights.

Second, to the best of our knowledge this is the first study that examines minority expropriation in France. French firms have the possibilities to separate between voting rights and cash flow rights through pyramids, double voting rights shares and crossholding. Due to this complicated ownership structures, controlling have the opportunity to hold more control than their equity ownership indicates, which further amplify the entrenchment effect.

Third, we study the identity of shareholders. Most prior studies (Gelb, 2000 ; Labelle et Schatt, 2005 ; Attig et al., 2006) do not distinguish between family controlled firms and nonfamily controlled firms. As suggested before, the intensity of agency conflicts depend on the identity of the major shareholders (family/non family) and influence therefore the corporate disclosure. The French context is worth to study, La Porta, Lopez-de-Silances and Shleifer (1999) and Faccio and Lang (2002) find a prevalence of family controlled groups in France..

Finally, as suggested by Meek, Roberts and Gray (1995), understanding why firms invest in disclosure is useful not only for preparers and users of accounting information but also for regulators. Firms with high ownership concentration are less transparent than their counterparts. Should regulatory authorities impose more disclosure requirements on them? Moreover, French firms that want to attract foreign ownership should align their disclosure with international standard and offer higher disclosure transparency.

The remainder of this paper is organized as follows: section 2 reviews the Literature review and hypothesis; section 3 presents the research design and method; section 4 presents the results and their interpretations. Finally, we summarize and conclude in section 5.

\section{Literature review and hypothesis}

Our study focus on a new agency conflict that has been less studied in accounting literature and arises when ownership is concentrated, it opposes controlling shareholders to minority ones. This conflict is more relevant in an environment where investors are less protected such in civil law country like France (La Porta et al., 2000). Our research question deals with the way minority expropriation influence corporate disclosure level. We intend to study three aspects that determine minority expropriation intensity: ownership and control concentration 
(Gelb, 2000 ; Labelle et Schatt, 2005), separation of cash flow and control rights (Grossman et Hart, 1988 ; Harris et Raviv, 1988) and family ownership (Chau et Gray, 2002).

Healy and Palepu (2001) present six forces that affect managers' disclosure decisions from a financial perspective: capital market transaction, corporate control contests, stock compensation, litigation costs, proprietary costs, and management talent signaling. Disclosure studies can be classified into two broad categories. The first presents motivations to disclose information (agency costs, capital market transaction, stock compensation, corporate control contests and management talent signaling). The second category of studies examines incentives to withhold and retain information (litigation costs, proprietary costs). Main previous studies focus on traditional agency conflicts and argue that firms suffering from high agency costs between shareholders and managers are likely to offer high disclosure level. In fact, Healy and Palepu (2001) show that demand for financial reporting and disclosure arises from information asymmetry and agency conflicts between managers and outsiders. Similarly to this study and based on agency theory developments, Gelb (2000) finds that disclosure reduces information asymmetry between managers and shareholders and contribute therefore to reduce agency conflicts.

Berle and Means (1932) study the dispersion of the capital and the traditional agency problem resulting from information asymmetry between shareholders and managers. Recent studies show that the validity of the image of the modern corporation drawn by Berle and Means is limited particularly in non American firms (Shleifer et Vishny, 1986 ; La Porta, Lopez-deSilances et Shleifer, 1999 ; Faccio et Lang, 2002). In fact, many studies conducted in other developed countries show more significant concentrations of ownership (La Porta, Lopez-deSilances et Shleifer, 1999 ; Faccio et Lang, 2002) and even among the largest American firms, Shleifer and Vishny (1986) find a relative high ownership concentration.

One of the explanations that La Porta et al. (1999) and Roe (2001) suggest for the prevalence of blockholders in continental Europe is that the incapacity of the legal system to protect investors from potential manager's opportunism leads shareholders to obtain large shares blocks to monitor managers themselves. Lee (2004) argue that controlling shareholders can easily control and influence professional manager and that this situation gives them the possibility to manage the firm in their interest and often at the expense of minority shareholders (Shleifer et Vishny, 1997). 
Shleifer and Vishny (1986) argue that when the ownership is concentrated, the main agency conflict is between controlling shareholders and minority interest holders rather than between shareholders and managers. Johnson et al. (2000) use the term "tunnelling" to refer to "the transfer of resources out of a company to its controlling shareholder (who is typically also a top manager)"(Johnson et al., 2000, p. 3). Controlling shareholders participate to management and have incentives to profit from their proximity to operating activities and make decisions that expropriate minority shareholders' wealth, for example, by paying excessive compensation, acquiring perquisites or making investments that conflict with outsiders' interests.

Following La Porta et al. (1999) and Biebuyck et al. (2005), Villalonga and Amit (2006) and Ho and Wong (2001) notice that agency costs in firms where the capital is hold by few shareholders, are the consequence of interest conflicts between dominant shareholders and minority shareholders. The first have incentives to expropriate private benefits from the second. Moreover, because controlling shareholders hold large blocks of capital and voting rights, they can easily constrain managers to follow them. They can therefore have a total control of the firm in particularly their disclosure strategy. Controlling shareholders have incentives to reduce information disclosure in order to avoid the risk that minority shareholders will be conscious that their interest are in danger and avoid therefore minority contests. Consequently, these firms are likely to offer poor disclosure.

La Porta et al. (1999) find that 75\% of controlling shareholders in France are member of the management or the board. Chiang and Venkatesh (1988) notice that their position gives them the opportunity to obtain a free access to a wide range of information. This private information help them to make transactions and raise abnormal profit (Jaffe, 1974 ; Finnerty, 1976). They are therefore reluctant to disclose information to public in order to protect their position.

Fan and Wong (2002) examine the relation between ownership concentration, measured by the percentage of voting right of the ultimate shareholder and the quality of accounting information as measured by earning informativeness using a sample of 977 companies in seven East Asian economies. The authors argue that concentrated ownership create agency conflicts between controlling owners and outside investors leading controlling shareholders to report accounting information for self-interested purposes, which result in less credibility in the reported earnings as perceived by outside investors. The authors present the entrenchment 
effect (Morck, Scheifer et Vishny, 1988) to explain the relation between ownership concentration and disclosure. They suggest that "as controlling shareholders are entrenched by their effective control of the firms, their decisions that deprive the rights of minority shareholders are often incontestable in the weak legal systems in the region and by ineffective corporate governance mechanisms". Fan and Wong (2002) find that these firms offer poor disclosure quality.

When controlling shareholders hold large voting rights, they can easily control the firm because they don't need the complicity of other shareholders for the approval of their decision in the general meeting. They can influence many of the decision of the firm notably it disclosure strategy. Consequently, firms with a control concentration are likely to present poor disclosure.

Attig et al. (2006) argue that controlling shareholders have a selfish behavior. Indeed, to increase the chance of executing his plans, the controlling shareholder would limit and delay the disclosure of information in order to avoid the intervention of minority shareholders or to conduct them to take bad decisions based on inadequate information.

(Lakhal, 2006) examine the association between ownership concentration and voluntary disclosure and find that management earnings forecasts are positively associated to ownership and control concentration.

This discussion leads to the following testable hypotheses:

\section{H1: There is a negative relationship between disclosure level and both ownership and control concentration.}

Ben Amar et André (2006) examine the relation between the separation between voting and cash flow rights and performance in a Canadian context. They suggest that a large proportion of Canadian public companies have controlling shareholders (families) that often exercise control over voting rights while holding a small fraction of the cash flow rights. The authors do not find that separation of ownership and control has a negative impact on performance arguing that Canada offer good investor protection and that "contrary to other jurisdictions offering poor minority shareholder protection or poor corporate governance, separation of control and ownership is not viewed as leading to value destroying mergers and acquisitions, i.e., market participants do not perceive families as usingM\&A to obtain private benefits at the expense ofminority shareholders". 
La Porta et al. (1998, 2000) suggest that countries with a civil law system like France present low investor protection and higher private benefits of control. One example of low investor protection in France is the possibility to separate between voting and cash flow rights which allows one shareholder to control the firm while possessing relatively low ownership percentage. The main mechanism that allows the dissociation between ownership and control is settled by the law of 1966 (du code de commerce) that gives French firms the possibility of issuing shares with double voting rights when they are registered for at least two years. The deviation from "one-share, one-vote" rule increases the risk violating the interest of minority shareholders because controlling shareholders have often voting rights in excess of their cash flow rights, and don't support consequently all the consequence of their decision.

The results of Attig et al. (2006) show that stocks with greater deviations between ultimate control and ownership have a larger information asymmetry component of their bid-ask. The authors explain this result using the findings of Claessens et al. (2000), they sustain that the deviation of control from ownership is associated with more selfish behavior by the ultimate shareholder. Following Fan and Wong (2002), the authors suggest that to increase the chance of executing theirs plans, controlling shareholders have incentives to minimize and delay the disclosure to avoid that other shareholders intervene or to base their decisions on inadequate information.

Fan and Wong (2002) suggest "Moreover, due to the complicated pyramidal and crossholding ownership structures typical in East Asian companies, a significant number of controlling owners in the region actually possess more control than their equity ownership indicates, which further exacerbates the entrenchment effect". Controlling shareholders can expropriate minority interest benefits and enrich themselves through related party transactions in which profits are transferred to other companies they control. Consequently firms that separate voting rights and cash flow rights are likely to provide poor disclosure level. We thus state the following hypothesis:

\section{H2: there is a negative association between disclosure level and the dissociation between voting rights and cash flow rights}

In France, family-owned and controlled companies are more in evidence than in AngloAmerican stock. La Porta et al. (1999) show that 50\% of French firms are controlled by family groups. In family controlled firms, family members actively participate to the management of the firm and staff in their board, therefore, they have access to all the 
information they need to assess the return of their investment. Moreover, according to Cormier et al. (2005) "firms with closely-held ownership are not expected to be responsive to public investors' information costs since the dominant shareholders typically have access to the information they need". These families need less external financing, therefore, external information demand is low. As dominant shareholders, families have less incentive to disclose (Chau et Gray, 2002). Using a sample of 60 listed firms in Singapore and 62 firms listed in Hong Kong in 1997, Chau and Gray (2002) test the relation between ownership structure and voluntary disclosure using the Meek et al. index (1995) to measure disclosure level. Consistent with the information financing need hypothesis, the authors find a negative relation between family control and voluntary disclosure.

Ho and Wong (2001) examine the relationship between corporate governance and voluntary disclosure quality using a sample of 98 listed firms in Hong Kong where family firms are prevalent. The authors find a negative relation between family members in the board and voluntary disclosure. They suggest that boards dominated by family members don't control manager to protect the interest of minority shareholders but their role is to vote decisions that maximize the interest of the family. Therefore, these family shareholders can easily expropriate minority shareholders since they have the support of the board to execute their plan. We suggest then that minority expropriation risk is higher in family firms then their counterparts. Family controlled firm have incentives to limit disclosure in order to continue to easily expropriate private benefit.

Compared to their counterparts, family firms face less severe agency problem due to the separation of ownership and management (type I) but more severe agency problem that arise between controlling and minority shareholders (type II) (Ali, Chen and Radhakrishnan, 2007). The difference between these two agency conflicts determines the direction of the relation between family control and disclosure. We suppose that the increase of type II conflict exceed the decrease of type I conflict and state the following hypotheses:

H3: there is a negative association between disclosure level and family ownership

\section{Research design and method}

This section presents the research design. 


\subsection{The sample}

The sample was selected from French firms listed on the Paris Stock Exchange and part of the SBF 120 index in 2004 (120 in total). The first step consists in selecting only industrial and commercial firms. We eliminate financial and insurance companies (16 firms) because of their specific disclosure requirements and financial characteristics. Second, 18 companies were excluded from the sample because of a lack of data. Finally, we eliminate 3 outliers. The final sample is composed of 81 companies, as shown in Table 1. A list of the companies included in the sample is reported in the Appendix.

\section{$* * *$ Insert Table 1 about here $* * *$}

We selected the period 2001-2004 because of information availability about Analyst earning data from IBES historical database.

\subsection{Variables and measurement}

The disclosure quality is a very difficult variable to measure in a French context as there is no organization that offers a disclosure rating such as the AIMR/CIC (Association of Investment Management Research), and the FAF (Financial Analysts Federation Corporate Information Committee) in USA.

Nelson Sofres Institute conducted a survey for AGEFI and Euronext in 2000 to nominate the prize of the best annual report and the best investor relations. The first step of this contest is to develop a shortlist of SBF120 companies that good annual report/investor relations quality. The second step consists of electing the prize for the best annual report/investor relations Labelle and Schatt (2005) use this study to measure disclosure quality. However, this measure offers a binary proxy which limits the number of methodologies that can be used (LOGIT).

Many previous studies have developed disclosure index to measure disclosure level or quality (Meek, Roberts et Gray, 1995 ; Botosan, 1997 ; Michaïlesco, 1999 ; Depoers, 2000). Nevertheless, this methodological approach has been recently criticized (Chavent et al., 2006). The authors present three limitations to this approach. First, the disclosure index is often determined by summing several items that can be weighted or unweighted. However, there is no dominant practice and the question of who should weight the items remains unanswered. Second, including too many independent variables may create a multicollinearity difficulty. Third, the form of the relationship between dependent and independent variables is 
not always known (Lang et Lundholm, 1993). Chavent et al.(2006) sustain that a 'classical' linear regression is not always the most suitable tool, and propose the use of a rank regression. Following Lang and Lundholm (1996), Barron et al. (1999) examine the relationship between analyst earning forecast characteristics and disclosure level. The results of these studies show that disclosure level is negatively associated to earning forecast error and earning forecast dispersion.

Dumontier and Maghraoui (2006) argue that " the information content of accounting numbers can't be observe directly, they are commonly measured using a proxy of information asymmetry". One of the categories used to proxy information asymmetry is based on analyst earning forecasts : forecast error (Labelle, Francoeur et Martinez, 2007), forecast dispersion (Daley, Senkow et Vigeland, 1988 ; Brown, 1997 ; Barron et al., 1998). We choose analyst forecast dispersion to measure disclosure level. Analyst data is taken from the IBES summary tape.

We include 3 proxies for ownership structure relying on Demsetz and Lehn's (1985) measures. We measure capital concentration by the Herfindhal index, calculated by summing the squared percentages of capital held by each shareholder. We also measure the percentage of voting rights held by the largest and the second largest shareholder. Bebchuk and Kahan (1999) present mechanisms that allow a controlling shareholder to maintain complete control of the firm even while he owns a relative low percentage of total shares. Indeed, issuing two categories of shares, shares with voting rights and shares without, results in separating voting rights and cash flow rights. We use a second ownership concentration variable denoted VOT1 and VOT2 which take into consideration control and voting rights. We introduce a dummy variable FAM when a firm is controlled by a family. Finally, we introduce four control variables: LNTA, COT, USCOT CAC40 and DEBT. LNTA measures the size of the firm. COT is a dummy which equals one if the firm is cross listed and 0 otherwise. USCOT is a dummy which equals one if the firm is listed in USA and 0 otherwise CAC40 is a dummy which equals one if the firm is included in the CAC40 index and 0 otherwise.

\section{$* * *$ Insert Table 2 about here ${ }^{* * *}$}

Table 2 summarizes the definitions and measurements of all variables used in this study. Data on ownership structure are taken directly from the firm's annual reports or from their official 
web sites. Earning forecasts are taken from IBES database. Finally, other accounting and financial data were collected from the Compustat database.

The summary descriptive statistics show that the average percentage of voting rights of the major shareholder is $34.9 \%$ and the average herfindhal index is 0.14 . These high values prove that ownership and control are concentrated in French firms. Theses results are coherent with La Porta, Lopez-de-Silances et Shleifer (1999) findings. We find that $45.57 \%$ of firms in the sample are controlled by families. This result is similar to Faccio et Lang (2002) findings. As expected, the descriptive statistics reveal that most of sample firms proceed to a separation between voting and cash flow rights (63\% of our firms use double voting rights) and the average voting rights of the dominant shareholders exceed his cash flow rights of $24 \%$. These results proved ownership concentration, the predominance of family controlled firms and the separation between ownership and control in France which leads us to examine type II agency conflicts (controlling vs minority shareholders).

\section{$* * *$ Insert Table 3 about here $* * *$}

\subsection{Method}

We use a panel data regression to examine the effects of the independent variables on the disclosure level.

The regression equation is formulated as follows:

$$
\begin{aligned}
& D I S C L=a_{0}+a_{1} V O T 1+a_{2} V O T 2+a_{3} H E R F I+a_{4} V A+a_{5} D O U B L E+a_{6} F A M+a_{7} C O T \\
& +a_{8} D E B T+a_{9} L N T A+a_{10} C A C 40+a_{11} U S C O T+a_{12} \text { EPSVAR }+\varepsilon
\end{aligned}
$$

\section{Results and discussion}

The correlation matrix show many correlations among the variables introduced in the regression, we therefore try to avoid putting them together which results in three models M1 M2 and M3. We discuss hereafter the results of M1, M2 and M3.

We test the presence of specific effects. The chow test reveals the presence of specifics effects. We then use the Hausman test (1978) to determine if they are random effects or fixed effects. The probability of the test is superior to $10 \%$ we can't then reject the null hypothesis $\mathrm{H} 0$ and decide to use random effect regression. Our time dimension is limited. Probably our result is due to the fact that ownership structure doesn't move a lot in a short period of 4 
years. We test for the presence of autocorrelation and heterosedaskicity and find that our data suffer from the two. We correct it using the command $x \operatorname{tgls}$ of STATA.

We use the opposite of earning forecast dispersion (STD) which is a proxy of information asymmetry to measure disclosure level (DISCL). Our independent variable DISCL equals the opposite of earning forecast standard deviation $(\mathrm{DISCL}=-\mathrm{STD}$ that we collect from IBES database.

Table 6 shows the results of the panel regression. Coefficients and Z-statistics are respectively reported. First, it is important to notice that the results of the three models M1, M2 and M3 show a positive and significant relation between STD and HERFI and VOT1. These results suggest a negative association between disclosure level and ownership and control concentration. These results confirm our first hypothesis. Firm with high ownership concentration suffer from more minority expropriation then their counterparts. This risk is higher when the first shareholders possess high voting rights which allow him to vote decision at the expense of minority shareholders without the need to the approval of other shareholders. One explanation of the negative association between disclosure quality and ownership concentration is that controlling shareholders have possibilities to expropriate minority shareholders. They have therefore incentive to reduce disclosure level in order to exploit private benefits of control and avoid minority shareholders contest. Consequently, entrenched managers of controlled firms have little incentives to provide high disclosure level. Our results are in accordance with Ho and Wong (2001), Chau and Gray (2002) and Eng and Mak (2003).

Labelle et Schatt (2005) test a non monotonous relation between ownership dispersion and disclosure quality suggestion that when insiders (managers and controlling shareholders) hold large blocks of capital they use to improve disclosure to get advantage as better liquidity and value increase due to disclosure as suggested by (Verrecchia, 1983 ; Welker, 1995). On the contrary, in a case of ownership dispersion, managers improve disclosure to decrease type I agency costs (between manager and shareholders). We test this assumption but we find no evidence for this relation.

Second, the regression results show a positive relation between STD and DOUB. Firm issuing double voting right offer low disclosure level. As we conjectured earlier, the separation between cash flow rights and voting rights amplify the agency problem between controlling shareholders and minority shareholders. When controlling shareholders hold voting rights in 
excess of their control rights, they have more incentives to exploit non-controlling shareholders since they may not pay for all the consequences of their decision. Consequently, they have incentive to retain information inside the company in order to avoid the intervene of non-controlling shareholders. However, we find no significant association between the coefficient of separation between voting rights and cash flows rights of the first shareholders and disclosure level. This variable presents problem of normality, one possible explanation is that our variable is not a good measure of the intensity of the dissociation between voting rights and cash flow.

One explanatory variable related to family ownership is introduced in equation M1, M2 and M3. We suggest earlier that firms controlled by families have little incentive to disclose information to the public for many reasons (Chau et Gray, 2002). First, the demand for information in such companies is relatively weak because the major providers of finance already have that information; these families staff many of the senior positions themselves. Second, these families are controlling shareholders, they have incentives to retain information and expropriate minority shareholders and third these firms suffer from more severe type II conflict.

We find a significant association between disclosure level and family control, nevertheless the coefficient sign is opposite to our prediction. Our hypothesis 3, which predicts that family control influences negatively disclosure level, is not supported. However this result is similar to Ali et al. (2007) findings on a sample of American firms part off S\&P 500. The authors argue that "compared to non-family firms, family firms face less severe agency problems due to the separation of ownership and management, but more severe agency problems that arise between controlling and non-controlling shareholders". Consequently, the difference in the quality of disclosure between family and non-family firms would depend on the difference in the severity of their Type I and Type II agency. Ali et al. (2007) find that family firms report better quality earnings and are more likely to warn for a given magnitude of bad news,

Our models include firm characteristics as control variables. We find a positive and significant association between US listing and disclosure level. Firms that are listed on the US Stock Exchange are subject to several information requirements than the French ones. Moreover, the American market is the first financial market and the more active. It requires from firms to comply with more mandatory disclosure. American investors are used to high corporate governance practices particularly high transparency level; therefore they are more 
demanding in term of information then the French ones. Our result is in accordance with the one found by Labelle and Schatt (2005) and Lakhal (2006).

We find that lower leverage is related to greater disclosure. Our result is aligned with Eng and Mak (2003). These authors suggest that "increased leverage is expected to reduce disclosure because leverage helps control the free cash flow problem, and the agency costs of debt are controlled through restrictive debt covenants in debt agreements rather than increased disclosure of information in annual reports (Jensen, 1986)".

We find that disclosure level is negatively associated to firm size. We explain this relation using proprietary cost and litigation cost theory frameworks. Larger firms face more severe proprietary costs because of higher competition intensity among them. Consequently, they disclose less information to public in order to avoid competitive disadvantage. Our result can be also explained using the litigation cost theory development (Francis, Philbrick et Schipper, 1994). Healy et Palepu (2001) suggest that litigation can potentially reduce managers' incentives to provide disclosure, particularly of forward-looking information. The author argue that "this is likely to arise if managers believe that the legal system penalizes forecasts made in good faith because it cannot effectively distinguish between unexpected forecast errors due to chance and those due to deliberate management bias"(Healy et Palepu, 2001, p. 423). Large firms reduce their corporate disclosure in order to reduce the cost of litigation. Finally, the coefficient of the variable EPSVAR is not significant which suggest no evidence on the relation between disclosure and performance.

\section{*** Insert Tables 4-5-6 about here a ** $^{* *}$}

\section{Conclusion}

In this paper four new determinants of the level of disclosure are identified using agency theory: ownership and control concentration, the existence of double voting share, family ownership. French firms seems to be a suitable setting to test the impact of minority expropriation on disclosure because of the limited academic exploration on the topic and the high level of ownership concentration of French firms increasing controlling private benefits. Consistent with the predictions of agency theory, we find that managers provide higher disclosures when the capital is less concentrated i.e. the level of public ownership is high. In a 
context of capital concentration, controlling shareholders retain information in order to expropriate minority shareholders and exploit private benefits.

Many studies show a negative association between disclosure quality and ownership concentration in a US context (Gelb, 2000) characterized by capital dispersion and the prevalence of the agency conflict between shareholders and managers. The study of French firms allows us to examine the topic of corporate disclosures in a different ownership context from that of the US and to focus on the conflict opposing controlling shareholders to noncontrolling shareholders. After controlling for leverage, US listing, performance and size, we find a negative association between disclosure quality and ownership and control concentration, and existence of double voting rights. Our results show a positive association between family control and disclosure level and are consistent with the result found by Ali, Chen et Radhakrishnan (2007) on an American firm sample.

This study contributes to the disclosure literature by providing evidence on the impact of minority expropriation on the corporate disclosure practices. Our findings support prior studies (Gelb, 2000 ; Fan et Wong, 2002 ; Labelle et Schatt, 2005 ; Attig et al., 2006) and shows that investor requirements appear to be greater for firms with high levels of individual shareholding. 
Table 1: Sampling procedure

Companies listed on Paris Stock Exchange on

31 December 2004 and part of SBF 120

Financial companies

16

Companies with Missing annual report $\quad 10$

Companies with Missing data $\quad 8$

Outliers $\quad 3$

Final sample $\quad 81$

Table 2: Variable definitions

\begin{tabular}{|c|c|c|}
\hline Variable & Definition & Measurement \\
\hline \multicolumn{3}{|l|}{$\begin{array}{l}\text { Dependent } \\
\text { variable: }\end{array}$} \\
\hline DISCL & Disclosure level & $\begin{array}{l}\text { The negative absolute value of analyst } \\
\text { earning forecast standard deviation }\end{array}$ \\
\hline \multicolumn{3}{|l|}{$\begin{array}{l}\text { Independent } \\
\text { variables: }\end{array}$} \\
\hline HERFI & $\begin{array}{l}\text { Herfindhal index measuring } \\
\text { ownership concentration }\end{array}$ & The squared sum of shares percentages \\
\hline VOT1 & Large shareholder & $\begin{array}{l}\text { Percentage of voting rights held by the } \\
\text { largest shareholder }\end{array}$ \\
\hline VOT2 & Second shareholder & $\begin{array}{l}\text { Percentage of voting rights held by the } \\
\text { second largest shareholder }\end{array}$ \\
\hline FAM & Family ownership & $\begin{array}{l}\text { Dummy variable coded as } 1 \text { if the firm is } \\
\text { controlled by a family and } 0 \text { otherwise }\end{array}$ \\
\hline DOUBLE & Double voting shares & $\begin{array}{l}\text { Dummy variable coded as } 1 \text { if there is a } \\
\text { double voting shares and } 0 \text { otherwise }\end{array}$ \\
\hline VA & $\begin{array}{l}\text { Separation between property } \\
\text { and voting rights }\end{array}$ & $\begin{array}{l}\text { Voting rights divided by the portion of } \\
\text { shares of the largest shareholder }\end{array}$ \\
\hline LNTA & Size & Log of total assets \\
\hline COT & Foreign quotation & $\begin{array}{l}\text { Dummy coded as } 1 \text { if the firm is listed on } \\
\text { foreign market and } 0 \text { otherwise }\end{array}$ \\
\hline USCOT & US listing & $\begin{array}{l}\text { Dummy coded as } 1 \text { if the firm is listed on } \\
\text { US market and } 0 \text { otherwise }\end{array}$ \\
\hline DEBT & Leverage & Total liabilities divided by total assets \\
\hline $\mathrm{CAC} 40$ & CAC40 membership & $\begin{array}{l}\text { Dummy coded as } 1 \text { if the firm forms part } \\
\text { of the CAC } 40 \text { index and } 0 \text { otherwise }\end{array}$ \\
\hline
\end{tabular}




\section{Table 3: Summary statistics of continuous variables}

Summary statistics are based on a sample of 84 French listed firms included in the SBF120 index. FAM equals 1 if a large shareholder is a family and 0 otherwise, SO is coded 1 if executives benefit from stock option plans and 0 otherwise, COTATION equals 1 if the firm is cross listed and 0 otherwise, HERFI is concentration index equals to the sum of the squared shares percentages. VOT1 is voting rights of the first large shareholder, VA is the voting right of the first shareholder divided by his shares portion, DEBT is the ratio of total debt per total assets, SIZE is the log of total assets.

Descriptive statistics of continuous variables

\begin{tabular}{|l|rrrrrrr|}
\hline & Mean & $\begin{array}{c}\text { Standard } \\
\text { deviation }\end{array}$ & Median & Maximum & Minimum & $\mathbf{2 5 \%}$ & $\mathbf{7 5 \%}$ \\
\hline STD & 0.325 & 0.291 & 0.24 & 0.02 & 1.84 & 0.4 & 0.13 \\
HERFI & 0.14 & 0.143 & 0.088 & 0.544 & 0.001 & 0.02 & 0.223 \\
VOT1 & 0.349 & 0.23 & 0.323 & 0.84 & 0.018 & 0.139 & 0.546 \\
VOT2 & 0.087 & 0.079 & 0.06 & 0.38 & 0 & 0.036 & 0.121 \\
VA1 & 1.241 & 0.264 & 1.21 & 2.009 & 0.898 & 1 & 1.412 \\
LNTA & 8.241 & 1.677 & 8.274 & 11.712 & 4.836 & 6.89 & 9.632 \\
DEBT & 0.257 & 0.136 & 0.275 & 0.69 & 0 & 0.162 & 0.352 \\
\hline
\end{tabular}

Descriptive statistics of categorical variables

\begin{tabular}{|c|c|c|c|c|}
\hline Variables & & Frequency & Percentage & Total \\
\hline \multirow{3}{*}{ DOUB } & Test variables & & & \\
\hline & No double voting rights & 120 & 36.04 & 333 \\
\hline & Double voting rights & 213 & 63.96 & \\
\hline \multirow[t]{3}{*}{ FAM } & No family control & 166 & 54.43 & 305 \\
\hline & Family control & 139 & 45.57 & \\
\hline & Control variables & & & \\
\hline \multirow[t]{2}{*}{ EPSVAR } & Bad performance & 139 & 42.38 & 328 \\
\hline & Good performance & 189 & 57.62 & \\
\hline \multirow[t]{2}{*}{$\mathrm{COT}$} & No cross-listing & 221 & 66.37 & 333 \\
\hline & Cross-listing & 112 & 33.63 & \\
\hline \multirow[t]{2}{*}{ USCOT } & No US listing & 255 & 77.51 & 329 \\
\hline & US listing & 74 & 22.49 & \\
\hline \multirow[t]{2}{*}{$\mathrm{CAC} 40$} & No CAC40 membership & 218 & 64.88 & 336 \\
\hline & CAC40 membership & 118 & 35.12 & \\
\hline
\end{tabular}


Table 4: Correlation matrix

\begin{tabular}{|c|c|c|c|c|c|c|c|c|c|c|c|c|}
\hline & HERFI & VOT1 & VOT2 & DOUB & VA1 & FAM & EPSVAR & $\mathrm{COT}$ & USCOT & DEBT & LNTA & CAC40 \\
\hline HERFI & 1 & & & & & & & & & & & \\
\hline VOT1 & $\begin{array}{l}0.9078 * * \\
0.000\end{array}$ & 1 & & & & & & & & & & \\
\hline VOT2 & $\begin{array}{l}0.020 \\
0.726\end{array}$ & $\begin{array}{l}-0.021 \\
0.708\end{array}$ & 1 & & & & & & & & & \\
\hline DOUB & $\begin{array}{l}-0.005 \\
0.935\end{array}$ & $\begin{array}{l}0.2112 * * \\
0.000\end{array}$ & $\begin{array}{l}0.042 \\
0.446\end{array}$ & 1 & & & & & & & & \\
\hline FAM & $\begin{array}{l}0.2657^{* *} \\
0.000\end{array}$ & $\begin{array}{l}0.4276^{* *} \\
0.000\end{array}$ & $\begin{array}{l}0.049 \\
0.391\end{array}$ & $\begin{array}{l}0.4743 * * \\
0.000\end{array}$ & $\begin{array}{l}0.2439 * * \\
0.000\end{array}$ & 1 & & & & & & \\
\hline EPSVAR & $\begin{array}{l}0.042 \\
0.459\end{array}$ & $\begin{array}{l}0.012 \\
0.829\end{array}$ & $\begin{array}{l}-0.026 \\
0.646\end{array}$ & $\begin{array}{l}0.001 \\
0.992\end{array}$ & $\begin{array}{l}-0.073 \\
0.196\end{array}$ & $\begin{array}{l}-0.003 \\
0.959\end{array}$ & 1 & & & & & \\
\hline $\mathrm{COT}$ & $\begin{array}{l}-0.2480 * * \\
0.000\end{array}$ & $\begin{array}{l}-0.2886^{* *} \\
0.000\end{array}$ & $\begin{array}{l}-0.048 \\
0.388\end{array}$ & $\begin{array}{l}-0.2468^{* *} \\
0.000\end{array}$ & $\begin{array}{l}-0.022 \\
0.687\end{array}$ & $\begin{array}{l}-0.3388^{* *} \\
0.000\end{array}$ & $\begin{array}{l}-0.084 \\
0.129\end{array}$ & 1 & & & & \\
\hline LNTA & $\begin{array}{l}-0.2109^{* *} \\
0.000\end{array}$ & $\begin{array}{l}-0.2530 * * \\
0.000\end{array}$ & $\begin{array}{l}-0.1380^{* *} \\
0.013\end{array}$ & $\begin{array}{l}-0.088 \\
0.113\end{array}$ & $\begin{array}{l}0.107 \\
0.056\end{array}$ & $\begin{array}{l}-0.3170 * * \\
0.000\end{array}$ & $\begin{array}{l}-0.030 \\
0.593\end{array}$ & $\begin{array}{l}0.5116^{* *} \\
0.000\end{array}$ & $\begin{array}{l}0.3095^{* *} \\
0.000\end{array}$ & $\begin{array}{l}0.2770^{* *} \\
0.000\end{array}$ & 1 & \\
\hline CAC40 & $\begin{array}{l}-0.2890^{* *} \\
0.000\end{array}$ & $\begin{array}{l}-0.2805^{* *} \\
0.000\end{array}$ & $\begin{array}{l}-0.2047^{* *} \\
0.000\end{array}$ & $\begin{array}{l}-0.059 \\
0.287\end{array}$ & $\begin{array}{l}0.082 \\
0.139\end{array}$ & $\begin{array}{l}-0.1473 * \\
0.010\end{array}$ & $\begin{array}{l}-0.013 \\
0.818\end{array}$ & $\begin{array}{l}0.4294 * * \\
0.000\end{array}$ & $\begin{array}{l}0.2921^{* *} \\
0.000\end{array}$ & $\begin{array}{l}0.1714^{*} \\
0.002\end{array}$ & $\begin{array}{l}0.7446^{* *} \\
0.000\end{array}$ & 1 \\
\hline
\end{tabular}


Table 5: VIF (Variance Inflation Factor) value

\begin{tabular}{|lcc|}
\hline Variable & VIF & $\mathbf{1 / V I F}$ \\
\hline VOT1 & 9.47 & 0.105611 \\
HERFI & 8.53 & 0.117252 \\
SOEPS & 5.03 & 0.198825 \\
EPSVAR & 3.88 & 0.257653 \\
DOUB & 2.79 & 0.35866 \\
VA1 & 2.36 & 0.423709 \\
INVFOR & 2.16 & 0.463311 \\
SO & 2.09 & 0.479389 \\
INVFR & 1.66 & 0.60129 \\
FAM & 1.62 & 0.6162 \\
LNTA & 1.44 & 0.69273 \\
USCOT & 1.36 & 0.73756 \\
VOT2 & 1.2 & 0.835558 \\
Mean VIF & 3.35 & \\
\hline
\end{tabular}


Table 6: Generalized least squared regression ${ }^{\mathrm{a}}$

\begin{tabular}{|c|c|c|c|}
\hline \multicolumn{4}{|c|}{$\begin{array}{l}\text { STD is the independent variable that measure the opposite of disclosure level (STD=- } \\
\text { DISCL) }\end{array}$} \\
\hline & $1 \mathrm{~A}(1)$ & $1 \mathrm{~A}(2)$ & $1 \mathrm{~A}(3)$ \\
\hline \multirow[t]{2}{*}{ HERFI } & 0.23014 & 0.21349 & \\
\hline & $(0.030)^{* *}$ & $(0.061)^{*}$ & \\
\hline \multirow[t]{2}{*}{ VOT1 } & & & 0.11947 \\
\hline & & & $(0.074)^{*}$ \\
\hline \multirow[t]{2}{*}{ DOUB } & 0.07778 & & 0.06538 \\
\hline & $(0.016)^{* *}$ & & $(0.041)^{* *}$ \\
\hline \multirow[t]{2}{*}{ VA1 } & & 0.07966 & \\
\hline & & -0.16 & \\
\hline \multirow[t]{2}{*}{ FAM } & -0.09643 & -0.07663 & -0.0995 \\
\hline & $(0.003)^{* * *}$ & $(0.015)^{* *}$ & $(0.003)^{* * *}$ \\
\hline \multirow[t]{2}{*}{$\overline{\text { EPSVAR }}$} & -0.03833 & -0.0328 & -0.0378 \\
\hline & -0.163 & -0.245 & -0.171 \\
\hline \multirow[t]{2}{*}{ LNTA } & 0.03219 & 0.02991 & 0.03236 \\
\hline & $(0.001)^{* * *}$ & $(0.002)^{* * *}$ & $(0.001)^{* * *}$ \\
\hline \multirow[t]{2}{*}{ USCOT } & -0.06231 & -0.07347 & -0.06727 \\
\hline & $(0.089)^{*}$ & $(0.046)^{* *}$ & $(0.065)^{*}$ \\
\hline \multirow[t]{2}{*}{$\overline{\mathrm{DEBT}}$} & 0.2791 & 0.2944 & 0.27213 \\
\hline & $(0.008)^{* * *}$ & $(0.006)^{* * *}$ & $(0.010)^{* *}$ \\
\hline \multirow[t]{2}{*}{ Constante } & -0.03314 & -0.0717 & -0.03289 \\
\hline & -0.699 & -0.502 & -0.707 \\
\hline Number of observations & 285 & 278 & 285 \\
\hline Number of companies & 81 & 81 & 81 \\
\hline p-values in parentheses & & & \\
\hline
\end{tabular}

The sample is compose of 81 French listed companies included in SBF120 index in the period 20012004.STD measures analyst earning forecast dispersion (we use the standard deviation of the last month preceeding the fiscal year end). HERFI measures ownership concentration and eagal the sum of the square percentage of the capital held by shareholders. VOT1 measures control concentration, it egals the percentage of voting rights of the major shareholders. FAM mesure family control. VA1 and DOUB measure the degree of separation between voting and cash flow rights. VA1 egals the percentage of voting rights to cashflow rights of the first shareholder.

au rapport du pourcentage des droits de vote et le pourcentage des droits au capital du premier actionnaire. DOUB is a dummy that equals 1 if the firm issues double voting rights and 0 otherwise. USCOT is a dummy that equals 1 if the firm is listed in USA and 0 otherwise. LNTA and DEBT measure respectively the firm size and its debt ratio.

\footnotetext{
${ }^{a}$ We use white method to correct for heteroskedasticity and we use the command robust to correct for first order autocorrelation
} 
Appendix 


\begin{tabular}{|c|c|c|c|c|c|c|}
\hline \multicolumn{4}{|c|}{ Sociétés du SBF120 tirées de la base de données Thomson Financial } & \begin{tabular}{|l|}
$\begin{array}{l}\text { Sociétés } \\
\text { financières* }\end{array}$ \\
AGF-SA
\end{tabular} & \begin{tabular}{|l} 
Données \\
manquantes \\
dans la base \\
IBES ${ }^{* *}$ \\
\end{tabular} & \begin{tabular}{|l} 
Rapports annuels \\
manquants
\end{tabular} \\
\hline $\begin{array}{l}\text { Air France-KLM } \\
\text { Accor } \\
\text { AGF SA } \\
\text { Air France-KLM } \\
\text { Air Liquide R } \\
\text { Alcatel } \\
\text { Alstom SA } \\
\text { Altadis SA } \\
\text { Alten } \\
\text { Altran Technologies } \\
\text { April Group } \\
\text { Arcelor SA } \\
\text { Areva CI } \\
\text { Assystem } \\
\text { Atos Origin SA } \\
\text { ASF } \\
\text { AXA } \\
\text { Bacou-Dalloz SA } \\
\text { Beneteau } \\
\text { BIC } \\
\text { BNP Paribas } \\
\text { Bonduelle } \\
\text { Bouygues SA } \\
\text { BusinessObjects } \\
\text { Camaieu } \\
\text { Cap Gemini SA } \\
\text { Carbone-Lorraine } \\
\text { Carrefour } \\
\text { Casino Guichard-P } \\
\text { CGG Veritas } \\
\end{array}$ & $\begin{array}{l}\text { Ciments Français } \\
\text { Clarins } \\
\text { SA } \\
\text { CNP Assurances } \\
\text { Credit Agricole SA } \\
\text { SA } \\
\text { Eads } \\
\text { Eiffage } \\
\text { Elior } \\
\text { Essilor Int } \\
\text { Euler Hermes } \\
\text { Eurazeo } \\
\text { Euro Disney SCA } \\
\text { Euronext NV } \\
\text { Eurotunnel SA } \\
\text { Faurecia } \\
\text { Fimalac } \\
\text { France Telecom } \\
\text { Gecina } \\
\text { International } \\
\text { Generale De Sante } \\
\text { GFI Informatique } \\
\text { Groupe Danone } \\
\text { Groupe Steria SCA } \\
\text { Guyenne-Gascogne } \\
\text { Havas SA } \\
\text { Hermes International } \\
\text { Imerys } \\
\text { Ingenico } \\
\text { Ipsos }\end{array}$ & $\begin{array}{l}\text { Jcdecaux SA } \\
\text { Klepierre } \\
\text { L'Oreal } \\
\text { Lafarge } \\
\text { Lagardere Groupe } \\
\text { LVMH } \\
\text { M6-Metropole TV } \\
\text { Parfumeries } \\
\text { Medidep } \\
\text { Michelin } \\
\text { Natixis } \\
\text { Neopost SA } \\
\text { Nexans SA } \\
\text { NRJ Group } \\
\text { Oberthur Card Sys SA } \\
\text { Pagesjaunes } \\
\text { Pernod-Ricard } \\
\text { Peugeot SA } \\
\text { Pierre Et Vacances } \\
\text { PPR SA } \\
\text { Publicis Groupe SA } \\
\text { Remy Cointreau } \\
\text { Renault SA } \\
\text { Rexel } \\
\text { Rhodia } \\
\text { Rodriguez Group } \\
\text { Safran SA } \\
\text { Saint Gobain } \\
\text { Sanofi-Aventis } \\
\text { Schneider Electric } \\
\end{array}$ & $\begin{array}{l}\text { Scor SE } \\
\text { SEB SA } \\
\text { SES SA } \\
\text { Snecma } \\
\text { Societe Generale } \\
\text { Sodexho Alliance } \\
\text { Soitec } \\
\text { Sopra Group } \\
\text { Communication } \\
\text { Stmicroelect } \\
\text { Suez } \\
\text { Technip } \\
\text { Teleperformance } \\
\text { TF1 } \\
\text { Thales SA } \\
\text { Thomson } \\
\text { Total SA } \\
\text { Trigano } \\
\text { Ubisoft } \\
\text { Unibail-Rodamco } \\
\text { Unilog } \\
\text { Valeo SA } \\
\text { Vallourec } \\
\text { Veolia } \\
\text { Vinci SA } \\
\text { Vivendi Inc } \\
\text { Wendel } \\
\text { Zodiac SA }\end{array}$ & \begin{tabular}{|l|} 
AGF-SA \\
April Group \\
AXA \\
BNP Paribas \\
CGG Veritas \\
Assurances \\
Agricole SA \\
Euler Hermes \\
Eurazeo \\
Euronext NV \\
Klepierre \\
Natixis \\
Scor SE \\
Generale \\
Rodamco \\
Wendel \\
\end{tabular} & \begin{tabular}{|l|} 
Altadis SA \\
Camaieu \\
Pagesjaunes \\
Renault SA \\
SES SA \\
Snecma \\
Teleperforman \\
TF1 \\
Trigano \\
Vivendi Inc
\end{tabular} & $\begin{array}{l}\text { Areva Cl } \\
\text { ASF**** } \\
\text { Euro Disney SCA } \\
\text { Eurotunnel SA } \\
\text { Groupe Steria SCA } \\
\text { Hermes International } \\
\text { Vallourec } \\
\text { Zodiac SA }\end{array}$ \\
\hline \multicolumn{4}{|c|}{ Total : 118} & Total : 16 & Total : 10 & Total : 8 \\
\hline
\end{tabular}

** II s'agit le plus souvent de problème de correspondances avec IBES ticker

***Certains rapports annuels ont plus un caractère publicitaire et continnent très peu d'informations comptables

****1ère cotation en 2001 


\section{References}

Ali A., Chen T.-Y., Radhakrishnan S. (2007), " Corporate disclosures by family firms », Journal of Accounting and Economics, vol. 44, $\mathrm{n}^{\circ} 1-2$, pp. 238-286.

Attig N., FONG W. F., GADHOUM Y., LANG L. H. P. (2006), « Effects of large shareholding on information asymmetry and stock liquidity », Journal of Banking and Finance, vol. 30, pp. 2875-2892.

Barron O. E., Kile C. O., O'KeEfe T. B. (1999), « MD\&A Quality as Measured by the SEC and Analysts' Earnings Forecasts », Contemporary Accounting Research, vol. 16, $\mathrm{n}^{\circ} 1$, pp. 75-109.

Barron O. E., KIM O., LiM S. C., Stevens D. E. (1998), « Using analysts' forecasts to measure properties of analysts' information environment », Accounting Review, vol. $73, n^{\circ} 4$, pp. 421.

BeBchuK L. A., KaHAN M. (1999) « The "lemons effect" in corporate freeze-outs », Discussion Paper, Harvard Law School.

Ben AMar W., ANDRÉ P. (2006), « Separation of Ownership from Control and Acquiring Firm Performance: The Case of Family Ownership in Canada », Journal of Business Finance and Accounting, vol. 33, $\mathrm{n}^{\circ} 3 / 4, \mathrm{pp}$. 517-543.

Berle A. A., Means G. C. (1932), The Modern Corporation and Private Property, MacMillan, New York.

Biebuyck T., Chapelle A., Szafarz A. (2005) « Les leviers de contrôle des actionnaires majoritaires », Working paper, Université Libre de Bruxelles.

Botosan C. A. (1997), « Disclosure Level and the Cost of Equity Capital », The Accounting Review, vol. 72, n 3, pp. 323-349.

BROWN L. (1997), « Analyst forecasting errors: Additional evidence », Financial Analysts Journal, pp. 81-88.

ChAu G. K., GraY S. J. (2002), « Ownership Structure and Corporate Voluntary Disclosure in Hong Kong and Singapore », The International Journal of Accounting, vol. 37, $\mathrm{n}^{\circ} 2$, pp. 247-265.

Chavent M., Ding Y., Fu L., Stolowy H., Wang H. (2006), « Disclosure and determinants studies: An extension using the divisive clustering method (DIV) ", European Accounting Review, vol. 15, $\mathrm{n}^{\circ}$ 2, pp. 181-218.

Chiang R., VenKatesh P. C. (1988), « Insider Holdings and Perceptions of Information Asymmetry: A Note », Journal of Finance, vol. 43, n 4, pp. 1041-1048.

Claessens S., DJankov S., LANG L. H. P. (2000), « The separation of ownership and control in East Asian Corporations », Journal of Financial Economics, vol. 58, n 1-2 pp. 81112.

Daley L. A., Senkow D. W., Vigeland R. L. (1988), « Analysts' Forecasts, Earnings, Variability, and Option Pricing: Empirical Evidence », Accounting Review, vol. 63, ${ }^{\circ}$ 4, pp. 563.

Demsetz H., LeHN K. (1985), " The Structure of Corporate Ownership: Causes and Consequences. », Journal of Political Economy, vol. 93, n 6, pp. 1155-1177.

DEPOERS F. (2000), « L'offre volontaire d'information des sociétés cotées : concept et mesure », Comptabilité - Contrôle - Audit, vol. 6, n² 2, pp. 115-131.

Dumontier P., MAGHRAOUI R. (2006), « Adoption volontaire des IFRS, asymmétrie d'information et fourchettes de prix: l'impact du contexte informationnel. (French) », Comptabilité Contrôle Audit, vol. 12, n 2, pp. 27-48. 
ENG L. L., MAK Y. T. (2003), « Corporate Governance and Voluntary Disclosure », Journal of Accounting and Public Policy, vol. 22, $\mathrm{n}^{\circ} 4$, pp. 325-345.

FACCIO M., LANG L. H. P. (2002), " The ultimate ownership of Western European corporations », Journal of Financial Economics, vol. 65, n 3, pp. 365-395.

FAMA E. F., JENSEN M. C. (1983), « Separation of Ownership and Control », Journal of Law and Economics, vol. 26, pp. 301-325.

FAN J. P. H., WONG T. J. (2002), « Corporate ownership structure and the informativeness of accounting earnings in East Asia », Journal of Accounting and Economics, vol. 33, $\mathrm{n}^{\circ}$ 3, pp. 401-425.

FINNERTY J. E. (1976), « Insiders and market efficiency », Journal of Finance, vol. 31, $\mathrm{n}^{\circ} 4$, pp. 1141-1148.

Francis J., Philbrick D., SChIPPER K. (1994), « Shareholder Litigation and Corporate Disclosures », Journal of Accounting Research, vol. 32, n² 2, pp. 137-164.

GELB D. S. (2000), « Managerial Ownership and Accounting Disclosures: An Empirical Study », Review of Quantitative Finance \& Accounting, vol. 15, n 2, pp. 169-185.

Grossman S. J., HART O. D. (1988), « One Share/One Vote and the market for Corporate Contro », Journal of Financial Economics, vol. 20, n 1/2, pp. 175-202.

HARRIS M., RAVIV A. (1988), " Corporate control contests and capital structure », Journal of Financial Economics, vol. 20, pp. 55-86.

Healy P. M., PAlepu K. G. (2001), « Information asymmetry, corporate disclosure, and the capital markets: A review of the empirical disclosure literature "), Journal of Accounting and Economics, vol. 31, pp. 405-440.

Ho S., WonG K. S. (2001), "A study of the relationship between corporate governance structures and the extent of voluntary disclosure », Journal of International Accounting, Auditing \& Taxation, vol. 10, $\mathrm{n}^{\circ}$ 2, pp. 139-156.

JAfFe J. F. (1974), « Special Information and Insider Trading », Journal of Business \& Economic Studies, vol. 47, n², pp. 410-428.

Jensen M. C. (1986), « Agency Costs of Free Cash Flow, Corporate Finance, and Takeovers ", American Economic Review, vol. 76, n 2, pp. 323.

Johnson S., La Porta R., Lopez-De-Silanes F., Shleifer A. (2000), " Tunneling. », American Economic Review, vol. 90, n 2, pp. 22-27.

La Porta R., LOPEZ-De-Silances F., Shleifer A. (1999), « Corporate Ownership Around the World », Journal of Finance, vol. 54, n 2, pp. 471-517.

LA Porta R., LOPEZ-DE-Silanes F., Shleifer A., ViShNY R. (2000), « Investor protection and corporate governance », Journal of Financial Economics, vol. 58, n ${ }^{\circ} 1-2$, pp. $3-$ 27.

Labelle R., Francoeur C., Martinez I. (2007), « La gouvernance et la décision d'alerte aux résultats » In AFFI (Association Française de Finance), Bordeaux.

LABElle R., SchatT A. (2005), "Structure de propriété et communication financière des entreprises françaises », Finance - Contrôle - Stratégie, vol. 8, n 3, pp. 77-104.

LAKHAL F. (2006), "Les mécanismes de gouvernement d'entreprise et la publication volontaire des résultats en France. (French) », Comptabilité Contrôle Audit, vol. 12, $\mathrm{n}^{\circ}$ 2, pp. 69-92.

Lang M. H., Lundholm R. (1993), « Cross-Sectional Determinants of Analyst Ratings of Corporate Disclosures », Journal of Accounting Research, vol. 31, n 2, pp. 246-271.

Lang M. H., Lundholm R. J. (1996), "Corporate Disclosure Policy and Analyst Behavior », The Accounting Review, vol. 71, $\mathrm{n}^{\circ}$ 4, pp. 467-492.

LEE J. T. (2004), « Structure de l'actionnariat familial et performance des grands groupes coréens », Finance Contrôle Stratégie, vol. 7, n 4, pp. 143-166. 
MeeK G. K., Roberts C. B., Gray S. J. (1995), « Factors Influencing Voluntary Annual Report Disclosures by U.S., U.K. and Continental European Multinational Corporations ", Journal of International Business Studies, vol. 26, n 3, pp. 555-572.

MichaÏLESCO C. (1999), "Une étude empirique des déterminants de la qualité de l'information diffusées par les entreprises françaises au cours de la période 1991-1995 ", Comptabilité Contrôle Audit, vol. 5, n 1, pp. 83-108.

Morck R., Scheifer A., VishnY R. W. (1988), " Management Ownership and Market Valuation », Journal of Financial Economics, vol. 20, n 1, pp. 293-315.

SHLEIFER A., VishnY R. W. (1986), « Large Shareholders and Corporate Control », Journal of Political Economy, vol. 94, n 3, Part 1, pp. 461-488.

ShleIfER A., ViSHNY R. W. (1997), « A Survey of Corporate Governance », Journal of Finance, vol. 52, $\mathrm{n}^{\circ}$ 2, pp. 737-783.

VERRECCHIA R. E. (1983), « Discretionary disclosure », Journal of Accounting \& Economics, vol. $5, \mathrm{n}^{\circ} 3$, pp. 179-194.

Villalonga B., AMIT R. (2006), « How do family ownership, control and management affect firm value? », Journal of Financial Economics, vol. 80, n² 2, pp. 385-417.

Welker M. (1995), « Disclosure Policy, Information Asymmetry, and Liquidity in Equity Markets », Contemporary Accounting Research, vol. 11, n² 2, pp. 801-827. 